\title{
An Analysis of Healthy City Criteria Case Study: District 6 of Isfahan- Iran
}

\author{
Dr. Masoud Taghvaei
}

Full Professor of Geography and Urban Planning, University of Isfahan, Isfahan, Iran

\author{
Mohammad Moharamzadeh
}

Ph. D Student of Environmental Studies, Atatürk University, Turkey

Aazam khan Aghai

M.A Student of Geography and Urban Planning, University of Isfahan, Isfahan, Iran

\section{Jabbar Alizadeh Asl (Corresponding Author)}

Ph.D Student of Geography and Urban Planning, University of Isfahan, Isfahan, Iran

E-mail: alizadehali91@yahoo.com

Received: November 25, 2014 Accepted: December 8, 2014

doi:10.5296/emsd.v4i1.6827ＵRL: http://dx.doi.org/10.5296/emsd.v4i1.6827

\begin{abstract}
The growth of population and urbanization and consequently, the emergence of urban problems such as insufficient urban infrastructures, housing, green areas, etc., increase of various pollutions, degradation of air quality and as a result, prevalence of different diseases and physical and mental disorders among citizens have made the subject of "healthy man" the "center of sustained development", so that urban science scholars consider a "healthy city" as one of the routes to achieving "sustained urban development." A healthy city is one the quality of which is continuously improving and one which keeps providing its citizens with new opportunities. Therefore, urban health is very important and in this regard, economic, health, environmental, social and cultural factors of development play a crucial role. This study has analyzed and evaluated the conditions of district 6 of Isfahan, using 20 indicators ( 4 criteria) in terms of health, socio-cultural, economic and infrastructural-environmental aspects. Descriptive-analytic method has been employed and the data have been collected mainly
\end{abstract}


through a questionnaire which has been analyzed using SPSS and statistical tests such as independent and one-sample T-test as well as Pearson correlation coefficient. Results indicate that district 6 of Isfahan is not in favorable conditions in terms of healthy city criteria. Economic, infrastructural-environmental and health criteria are lower than the average level. Among the four criteria, only the socio-cultural criterion is higher than the average. There also exists a significant relation between the levels of these criteria, and citizens' gender and educational levels have had no impact on their attitudes toward healthy city criteria in district 6 of Isfahan. Finally, some suggestions have been presented for the improvement of healthy city criteria and indices in general and for district 6 of Isfahan in particular.

Keywords: City, Healthy city, Criteria of a healthy city, District 6 of Isfahan

\section{Introduction}

\subsection{Problem Statement}

Urbanization is an important challenge faced by urban managers and planners (C. Stephens et al., 2008), which is different in different parts of the world. However, the world's urban population in the less developed regions will be 1.9 billion in 2000 and 3.9 billion in 2030 (World Health organization, 2010), and between 20 and 30 cities of the world will have a population over 20 million within the next 15 years (Lynch, k, 2006). The world Health Organization (WHO) has warned about this, and has regarded "urban sprawl" as the main factor threatening the citizens' health in the $21^{\text {st }}$ century. It is estimated that over 60 percent of the world's population will be living in cities in 2025, which will have deteriorating effects on the citizens' health status (Nasrabadi, 2006), and consequently lead to a decrease in the capacity of urban infrastructures, deterioration and densification of the housings, rushing to the open spaces, degradation of air quality, a decrease in the rivers and canals' capacity for natural treatment of wastes, a reduction of the surface water resources, and pollution of water (Mousa, 2005). Although inequality in the environmental standards among the inhabitants of a city is not a new phenomenon in any of the world's cities, the astronomical differences of the cities have even widened in less developed countries due to the rise of socio-economic differences, as well as emergence of substandard dwellings (96).

A city should satisfy the citizens' needs and have a live and healthy economy. There should be tangible and constructive cooperation and participation in a city, the urban health level should increase, preventive and medical centers should be created and there should be a climate in which individuals have respect for the society and vice versa (The first Healthy City Symposium Proceedings, 1992). Nowadays, the citizens, especially the poor ones, immigrants and slum dwellers are suffering from pressures including degradation of public health level, poverty, shortage of water and housing, population density, false jobs, improper waste disposal system, insecure job conditions, insufficient governmental services, excessive consumption of hazardous materials, environmental pollution (Participating Organizations, 2006) and emission of pollution (Ziary et al., 2006). Therefore, development sustainability and maintaining the quality of life for man on the Earth planet depend on the rational growth and development of cities and reformation of their relation with the environment and natural resources (Ziary et al., 2006). The cities' lack of safety indicators including insufficient infrastructures and services 
particularly affects the health of the residents of poor and populous neighbourhoods (World Health organization, 2010), and the WHO believes that the key to improving community health should not be looked for merely in the health sector; different sectors of economic, environmental, social and cultural development play an important part in this regard (Nasrabadi, 2006). This research studies the health status of District 6 of Isfahan, using the socio-cultural, environmental, economic and health indicators in order to suggest strategies to improve the indicators.

\subsection{Need and Importance of the Research}

Urban health is of great importance, and urban health control is particularly taken into consideration. For instance, in developing countries, urban control can contribute to better life conditions with life expectancy of 75 years or more, whereas lower control on urban health will decrease life expectancy to its minimum (35 years) (World Health organization, 2010). Population growth in the $20^{\text {th }}$ century particularly in cities gave rise to the category of health. The results of the discussions of the planners and experts from different fields including the economic, social and cultural development sectors led to codification of a new approach to sustainable development with centrality of "health, the center of sustainable development". This thought in the 1980s led the WHO to put forward the subject of "healthy city", which was based on people's collaboration and participation for the purpose of achieving the health plan. Accordingly, the world has faced the interesting category of healthy city at the outset of the $21^{\text {st }}$ century. This issue is interesting due to the fact that almost all groups in a community are seeking a healthier place in which to live. These groups have chosen particular characteristics or features as their criteria for healthy city, depending on their knowledge and experience (Consulting Engineers Architects and Urban Development Water and Energy Research and Studies, 1993). Cities import water and food and export garbage, waste, and weather polluters, and it is very important to manage these imports and exports, which should be taken into consideration by the urban managers and planners. Isfahan is facing problems such as traffic, air pollution, noise, marginalization, shortage of water, scarcity of green space, and many other problems, and the urban managers should keep in mind that street system construction and the like does not amount to providing the citizens with facilities and services, and that they should generally direct much attention to "people's welfare and quality of life". Thorough and organized coordination and planning can help overcome such problems (The first Healthy City Symposium Proceedings, 1992). District 6 of Isfahan is located in the south of this city, and its demographic and infrastructural development can affect the citizens' well-being and life quality. The need and importance of the present research lies in the fact that the urban managers and planners' attention to the citizens' welfare and life quality results in "injection of healthy cities to the urban hierarchy system of the country".

\subsection{The Research Method}

Considering the purpose of the research, it is an applied research, and a descriptive-analytic case study considering the nature and method of the research. The data collection method is a combination of the documentary method and the survey method of questionnaire, and the participants are all the inhabitants of district 6 of Isfahan, including 11646 people according to 
the last official census in 2013 since it was impossible to study the whole population, Cocheran formula was used to calculate the sample size with the standard error of 5 percent and confidence level of 95 percent (Hafez niaa, 2008). Therefore, the sample size was calculated to be 322 people and eventually increased to 400 people in order to obtain more reliable results (Chronbach's alpha in all the criteria is more than 0.75). A random sampling method has been used in this research and attempts have been made to survey all the areas of district 6 . The data have been analyzed using methods of inferential statistics such as one-sample T-test, Pearson correlation and so on.

\subsection{The Research Area}

The city of Isfahan, as the third Iranian metropolis has 14 urban regions and a population of 1583609 people according to the population and housings census (www.sci.org.ir). The range of this study is district 6 of Isfahan, with a space of 11530000 square meters and a population of 116464 people in 2013 (www.mun6.Isfahan.ir).

\section{Fundamentals and Concepts}

Cities are considered the most manifest environment of life for human beings (Yghfory et al., 2011), and a characteristic of the current era is urbanization of population, growth of the cities, population, and consequently development of large and small cities (Mousa, 2005) as a principle for the increasing ratio of the world's population (Galeaa et al., 2005). Cities are often moving in contrast with the environmental criteria, play an important role in developing marginalized communities, social instability, and health problems, have linked with the phenomenon of "global warming", and are faced with multiple threats which affect urban health (World Health organization, 2010). People have gradually learned about insufficient health services and welfare status of cities since the 1970s, and the result of such awareness has been the codification of the strategy "health for all by 2000" proposed by WHO in 1970 (World Health Organization, 2000). Therefore, it is believed in a healthy community that mere lack of diseases cannot be considered an indicator for a healthy city. Rather, citizens should enjoy high-quality lives (Department of Health and Human Services, 2001), and for this purpose, they require a "precise planning, knowledge-based management and awareness of the indicators and criteria of a healthy city" in order to achieve "social welfare as the missing link in the modern cities".

"Health planning" is a relatively new expression made by those urban and regional planners who seek to bind the urban environment with the citizens' physical and mental health. The urban planners and authorities of safety and health affairs have not previously been in coordination with one another in making decisions on such fundamental issues as "social welfare, and improvement of human life and health", which has led to unwelcome development of the cities' physical space, destruction of the natural places of residence and biodiversity, more focus on automobiles in urban transportation, giving centrality to the cities' internal regions, reduction of the public spaces, and rise of slum residency by the classes with lower income (Thompson, Susan, 2007). However, the relation of urban planning and management with the community's health is not a new subject, but what has changed at present is acceleration of the societies' health crisis in both developing and developed countries 
(Thompson, Susan, 2007). Urban planning can practically improve healthy behaviors in different ways for both previously-existing and new areas. These methods include planning physical activities in cities where healthy food and security services with efficient costs are accessible and health services are provided and the roads are secure enough (World Health organization, 2010). Therefore, scholars of urban and regional science nowadays believe that a way of obtaining "sustainable urban development" is having "a healthy city"1

Since Almaty declaration was rectified in 1978, its main concern has centered around "international health", and WHO and UNICEF are working collaboratively in order to heighten first aids, the chief layer of health systems, by improving regional health systems and making use of social participation in order to support the health system(Ahmad 1998).

The first international conference on improving the status of health and safety in Ottawa (Canada) in 1986 issued a statement according to which the basic conditions for improving people's health are such factors as social stability, housing, training, food, income, stable ecosystem, sustainable resources, social justice and equality (Few, 2003), and subsequently the regional office opg WHO in Europe presented a suggestion to implement a small project for the purpose of improving the health level which started in an official ceremony in March 1986 in Lisbon (Portugal). Then, the healthy city project gradually began to work in European cities and then in some cities of the developing countries, so that nowadays almost every country has implemented this project in at least one of its cities (Hancock, 1986).

The second conference on environment and health was held in Helsinki in 1994, and the importance of urban health was prioritized for the first time. It was suggested in this conference that many affairs concerning the health of cities be assigned to the local authorities, while decisions were mostly made by the central government previously (Lawrence et al., 2009). Actually, the idea of healthy city was put forward in order to bring about a great change in maintaining environment and improving the health level and it has considerably been welcome by experts and authorities of health and urban issues (Rahnema et al., 2010). With the recent development of "new ideas of contemporary urban planning" in Iran's urban and regional studies, these concepts will gradually be implemented in urban development plans, and the "healthy city" idea is one of these new concepts in the turbulent atmosphere of Iranian metropolises such as the industrial, touristic city of Isfahan.

\section{Discussion}

\subsection{The Criteria and Indicators Evaluated and the Way of Encoding and Changing the Qualitative Information into Quantitative Data}

So far, different sources and references have put forward different indicators and criteria for healthy city, each corresponding with one aspect of the dimensions of life quality in healthy city. Some of these indicators are obtainable through censuses and statistical yearbooks, while some others should be extracted qualitatively from among the lives, cultures and ideas of the citizens, as the players of the "healthy city" game. As this research has been conducted in an

\footnotetext{
1. The healthy city doctrine was first posited in a conference in Torento, Canada, held to evaluate the results of Lalonde report_
} 
urban region in the form of a survey, focus has been placed on using criteria and indicators achievable via a questionnaire in the form of parallel and analogous scales. After studying and evaluating the indicators put forward in different sources and references, I chose 20 indicators or general and relatively precise sub-criteria (including diverse variables) in the form of different health, socio-cultural, economic and infrastructural-environmental sectors shown in Table 3. This research sought in general to find an answer to this question: how is the status of district 6 of Isfahan from the point of view of healthy city indicators from health, socio-cultural, economic and infrastructural-environmental aspects?

Table 3. The criteria, indicators and variables of healthy city used in this research

\begin{tabular}{|c|c|c|}
\hline criteria & Indicators (sub-criteria) & Indicator variables \\
\hline \multirow{5}{*}{ 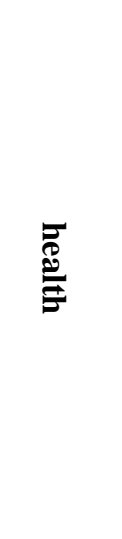 } & $\begin{array}{l}\text { 1- Status of health and medical facilities } \\
\text { and services }\end{array}$ & $\begin{array}{l}\text { Appropriate access to health-medical service centers, existence of medical cares } \\
\text { for all citizens, the status of medical services insurance etc. }\end{array}$ \\
\hline & 2- Physical and mental health & $\begin{array}{l}\text { Safety, sports and physical activities, avoiding smoking cigarettes and drugs, } \\
\text { lack of communicable or hereditary diseases, mental or psychological status etc. }\end{array}$ \\
\hline & 3- Preventive principles & $\begin{array}{l}\text { Public vaccination,- especially children below } 6 \text { years of age, preventing } \\
\text { communicable diseases, existence of health training workshops, pre-marriage, } \\
\text { during-pregnancy and fertility-control instructions. }\end{array}$ \\
\hline & 4- Quality of nutrition and clothing & Healthy water, proper nutrition and clothing \\
\hline & 5- Quality of environment's health & $\begin{array}{l}\text { Waste disposal and reduction of environmental pollutions, cleanliness of the } \\
\text { streets, and public spaces and places }\end{array}$ \\
\hline \multirow{5}{*}{ 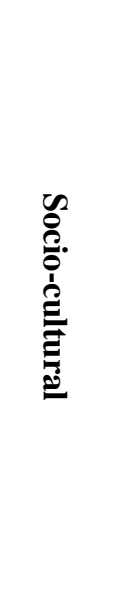 } & $\begin{array}{l}\text { 1- Rate of satisfaction with instructional, } \\
\text { cultural and sport-entertainment facilities } \\
\text { and services }\end{array}$ & $\begin{array}{l}\text { Libraries, schools, cinemas, exhibitions, parks and places for spending one's } \\
\text { free time, sport saloons and places. }\end{array}$ \\
\hline & 2- Social participation rate & $\begin{array}{l}\text { Participation in managing the urban and social affairs and local decisions, } \\
\text { holding ceremonies, sense of city and its facilities' belonging to all citizens and } \\
\text { responsibility for it, cooperation and collaboration ... }\end{array}$ \\
\hline & 3- Status of citizenship culture & $\begin{array}{l}\text { Type of behavior and clothing, observing the rules and regulations, respecting } \\
\text { the values and norms ... }\end{array}$ \\
\hline & 4- Social security status & Types of crimes, theft, violence, drug trafficking, mental security ... \\
\hline & 5- Literacy and awareness status & $\begin{array}{l}\text { Educational literacy, general information, computer literacy, the rate of } \\
\text { studying ... }\end{array}$ \\
\hline \multirow{5}{*}{ 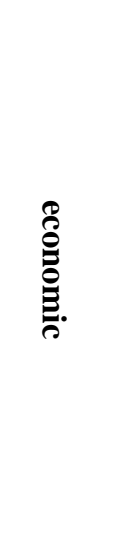 } & $\begin{array}{l}\text { 1- Loans from banks and financial and } \\
\text { credit institutions }\end{array}$ & Receiving and repaying loans, possibility and profit of investment ... \\
\hline & $\begin{array}{l}\text { 2- Satisfaction with job opportunities and } \\
\text { employment }\end{array}$ & $\begin{array}{l}\text { Fair distribution of the job opportunities, job security, useful and non-false } \\
\text { job ... }\end{array}$ \\
\hline & $\begin{array}{l}\text { 3- Satisfaction with income and economic } \\
\text { status }\end{array}$ & $\begin{array}{l}\text { Level of income, affording the costs and having purchasing power, possibility of } \\
\text { saving ... }\end{array}$ \\
\hline & $\begin{array}{l}\text { 4- Satisfaction with distribution of loans } \\
\text { and economic facilities }\end{array}$ & Subsidies, fair distribution of the wealth and economic resources and ... \\
\hline & $\begin{array}{l}\text { 5- Satisfaction with the way of paying the } \\
\text { cost of government services }\end{array}$ & $\begin{array}{l}\text { Taxes and charges, costs of water, electricity, gas, telephone, transportation } \\
\text { and ... }\end{array}$ \\
\hline
\end{tabular}




\section{Macrothink}

Environmental Management and Sustainable Development

ISSN 2164-7682

2015, Vol. 4, No. 1

\begin{tabular}{|c|c|c|}
\hline \multirow{5}{*}{ 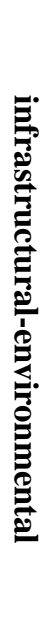 } & $\begin{array}{l}\text { 1- The rate of types of environmental } \\
\text { pollutions }\end{array}$ & Noise, visual, weather, soil ... \\
\hline & $\begin{array}{l}\text { 2- Existence of unwelcome physical } \\
\text { spaces and uses incompatible with life }\end{array}$ & $\begin{array}{l}\text { Marginalized areas, workshops, industries and professions such as carpentry, } \\
\text { door and window makers, confectioneries, and ..., terminals, unauthorized } \\
\text { constructions, ... }\end{array}$ \\
\hline & 3- Green space status & $\begin{array}{l}\text { Parks, the green spaces of the squares and boulevards, urban jungles, home } \\
\text { gardens, green roofs, ... }\end{array}$ \\
\hline & $\begin{array}{l}\text { 4- Optimal consumption of energy and } \\
\text { resources }\end{array}$ & $\begin{array}{l}\text { Use of insulating glass, and insulating the constructions, savings in consuming } \\
\text { water, electricity, gas, and other resources, segregation of the garbage at } \\
\text { home, ... }\end{array}$ \\
\hline & $\begin{array}{l}\text { 5- Rate of using clean and less polluting } \\
\text { technologies to do the affaires }\end{array}$ & $\begin{array}{l}\text { Information and communication technology (ICT), non-motorized vehicles and } \\
\text { public transportation ... }\end{array}$ \\
\hline
\end{tabular}

This has been extracted from the sources (2-16-27-28-31-32-33-34-35), and indexed by the writers and their field studies, 2013. The qualitative information of the indicators was gathered in the form of Lakert 5-degree scale from very unfavorable (or very bad, very weak, very rare, and very inappropriate, depending on the type of index) to very favorable (or very good, excellent, very much, very appropriate). Then, with the integration of the positive and negative indicators ${ }^{2}$ were encoded (Table 4) and inserted in the SPSS software, and the preparations for the tests and inferential analysis of the data were made. Different indicators and criteria will be analyzed by the one-sample T-test.

Table 4. Encoding way of the indicators of healthy city

\begin{tabular}{|c|c|c|c|c|c|}
\hline Option(reply) & Very unfavorable & unfavorable & average & favorable & Very favorable \\
\hline code & 1 & 2 & 3 & 4 & 5 \\
\hline
\end{tabular}

\subsection{Health Criteria and Indicators}

Health criteria and indicators are regarded as important characteristics of a healthy city. The results of the descriptive and analytic analyses of one-sample T-test of the health indicators of district 6 of Isfahan have been shown in Table 5 .

Table 5. One-sample T-test for assessing the health criterion

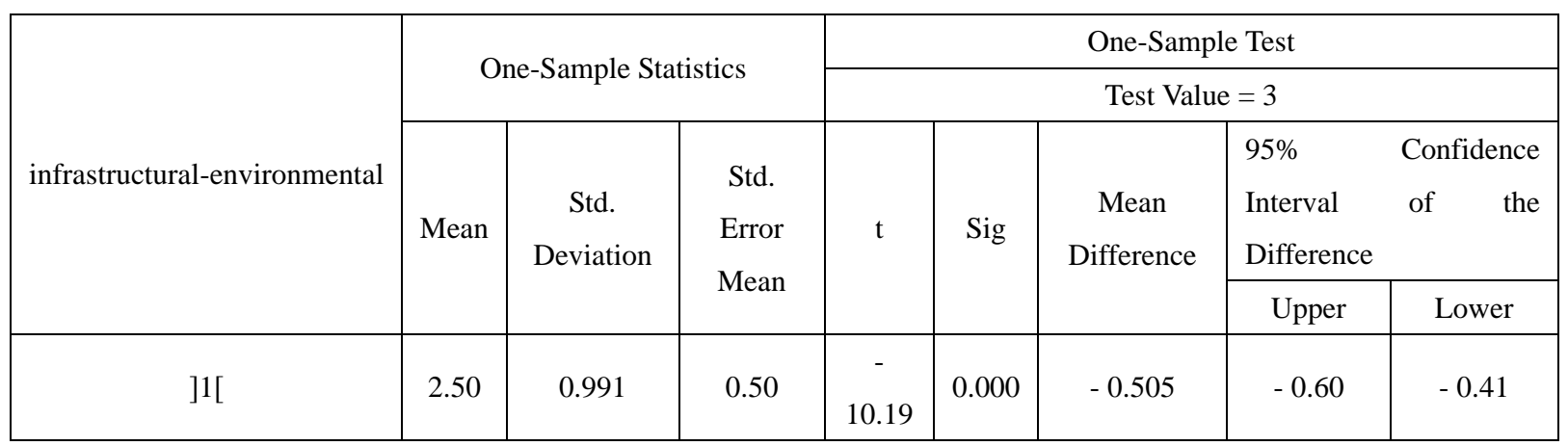

2 - some indicators, for instance the environmental pollutions index are negative, and they will have a negative impact on the criterion's favorableness if they are many or too many. Therefore, in order to align them with the other indicators and doing similar tests and analyses, the negative indicators are encoded in reverse. For instance, unlike the positive indicators, code 1 was given to the reply "very much", and code 5 was given to the reply "very little". 


\begin{tabular}{|c|c|c|c|c|c|c|c|c|}
\hline$] 2[$ & 3.30 & 0.993 & 0.047 & 6.325 & 0.000 & 0.295 & 0.20 & 0.39 \\
\hline$] 3[$ & 2.62 & 1.067 & 0.053 & $\begin{array}{c}- \\
7.168\end{array}$ & 0.000 & -0.383 & -0.49 & -0.28 \\
\hline$] 4[$ & 3.43 & 0.876 & 0.044 & 9.765 & 0.000 & 0.428 & 0.34 & 0.51 \\
\hline$] 5[$ & 2.70 & 1.165 & 0.058 & - & 0.000 & -0.298 & -0.41 & -0.18 \\
\hline
\end{tabular}

Because the significance level calculated for all the indicators investigated (sig=0.000) is less than the considered level of significance $(\alpha=0.05)$, therefore, we can rely on the results of the test for the whole indicators. Considering the results obtained, one can say that the status of the two indicators of "food and clothing quality" and "the citizens" physical and mental health" is higher than the average and at a relatively good level, as the average of these two indicators has been higher than the average. Therefore, difference with upper and lower bound average and their T-statistics shows a relatively high and positive number. As the average of the three remaining health indicators is lower than the average level and the T-statistics is negative, we can conclude that their status is not favorable or even at an average level. Amongst all, the worst status goes to health and medical facilities and services, which is at a relatively weak level.

\subsection{Socio-Cultural Criteria and Indicators}

After encoding the data related to the socio-cultural indicators of a healthy city, they were tested (Table 6). The results of the "social participation" indicator test are not reliable as sig has been higher than 0.05. However, the result of the other indicators' test is reliable and interpretable. According to these results, the index "educational-cultural facilities and services" is in an unfavorable status, and the indicators of "social security", "literacy and awareness", "citizenship culture" and "social participation" are respectively in a status above the average and relatively favorable.

Table 6. One-sample T-test for assessing the socio-cultural criterion

\begin{tabular}{|c|c|c|c|c|c|c|c|c|}
\hline \multirow{4}{*}{ infrastructural-environmental } & \multirow{2}{*}{\multicolumn{3}{|c|}{ One-Sample Statistics }} & \multicolumn{5}{|c|}{ One-Sample Test } \\
\hline & & & & \multicolumn{5}{|c|}{ Test Value $=3$} \\
\hline & \multirow[t]{2}{*}{ Mean } & \multirow[t]{2}{*}{$\begin{array}{c}\text { Std. } \\
\text { Deviation }\end{array}$} & \multirow[t]{2}{*}{$\begin{array}{l}\text { Std. } \\
\text { Error } \\
\text { Mean }\end{array}$} & \multirow[t]{2}{*}{$\mathrm{t}$} & \multirow[t]{2}{*}{ Sig } & \multirow[t]{2}{*}{$\begin{array}{c}\text { Mean } \\
\text { Difference }\end{array}$} & $\begin{array}{l}95 \% \\
\text { Interval } \\
\text { Differenc }\end{array}$ & $\begin{array}{l}\text { Confidence } \\
\text { of the }\end{array}$ \\
\hline & & & & & & & Upper & Lower \\
\hline$] 1[$ & 2.72 & 0.998 & 0.50 & $\begin{array}{c}- \\
5.66\end{array}$ & 0.000 & -0.283 & -0.38 & -0.18 \\
\hline$] 2[$ & 3.02 & 1.229 & 0.061 & 0.285 & 0.776 & 0.018 & -0.10 & 0.14 \\
\hline$] 3[$ & 3.22 & 0.823 & 0.041 & 5.287 & 0.000 & 0.218 & 0.14 & -0.30 \\
\hline$] 4[$ & 3.45 & 0.836 & 0.042 & 10.64 & 0.000 & 0.445 & 0.36 & -0.53 \\
\hline$] 5[$ & 3.40 & 0.843 & 0.042 & 9.37 & 0.000 & 0.395 & 0.31 & 0.48 \\
\hline
\end{tabular}

\subsection{Economic Criteria and Indicators}




\section{Macrothink}

The data related to the economic indicators were inferentially tested (Table 7), and due to the fact that the significance level of all the indicators $(\operatorname{sig}=0.000)$ has been lower than the considered significance level $(\alpha=0.05)$, significance of the test is acceptable for all the indicators.

Table 7. One-sample T-test for assessing the economic criterion

\begin{tabular}{|c|c|c|c|c|c|c|c|c|}
\hline \multirow{4}{*}{ infrastructural-environmental } & \multirow{2}{*}{\multicolumn{3}{|c|}{ One-Sample Statistics }} & \multicolumn{5}{|c|}{ One-Sample Test } \\
\hline & & & & \multicolumn{5}{|c|}{ Test Value $=3$} \\
\hline & \multirow[t]{2}{*}{ Mean } & \multirow[t]{2}{*}{$\begin{array}{c}\text { Std. } \\
\text { Deviation }\end{array}$} & \multirow[t]{2}{*}{$\begin{array}{l}\text { Std. } \\
\text { Error } \\
\text { Mean }\end{array}$} & \multirow[t]{2}{*}{$\mathrm{t}$} & \multirow[t]{2}{*}{ Sig } & \multirow[t]{2}{*}{$\begin{array}{c}\text { Mean } \\
\text { Difference }\end{array}$} & $\begin{array}{l}95 \% \\
\text { Interval } \\
\text { Difference }\end{array}$ & $\begin{array}{l}\text { Confidence } \\
\text { of the }\end{array}$ \\
\hline & & & & & & & Upper & Lower \\
\hline$] 1[$ & 2.50 & 0.991 & 0.50 & $\begin{array}{c}- \\
10.19\end{array}$ & 0.000 & -0.505 & -0.60 & -0.41 \\
\hline$] 2[$ & 2.57 & 0.746 & 0.037 & $\begin{array}{c}- \\
11.65\end{array}$ & 0.000 & -0.435 & -0.51 & 0.36 \\
\hline ]3[ & 2.54 & 0.970 & 0.049 & -9.58 & 0.000 & -0.465 & -0.56 & -0.37 \\
\hline$] 4[$ & 2.41 & 0.908 & 0.045 & $\begin{array}{c}- \\
12.94\end{array}$ & 0.000 & -0.588 & -0.68 & -0.50 \\
\hline$] 5[$ & 2.58 & 1.018 & 0.051 & $\begin{array}{c}- \\
18.30\end{array}$ & 0.000 & -0.433 & -0.52 & -0.32 \\
\hline
\end{tabular}

Based on the results of the test, one can say that the status of all the economic indicators investigated - for evaluating the status of economic criterion of healthy city in district 6 of Isfahan- is unfavorable, and the index "economic status" has the most unfavorable status of all the indicators.

\subsection{Infrastructural-Environmental Indicators}

One-sample T-test of the Infrastructural-environmental indicators shows that the significance of the index "existence of unwelcome physical spaces and uses incompatible with life" is not acceptable just because sig is higher than 0.05 , and the result of the test for the other four indicators is reliable at the confidence level of 95 percent and higher. According to the results of this test, all the Infrastructural-environmental indicators studied in district 6 are lower than the average and at an unfavorable or relatively unfavorable condition. The two indicators of "optimal consumption of energy and resources" and "rate of using the clean and less polluting technologies respectively had "better" and worse" conditions in comparison with other indicators.

Table 8. One-sample T-test for assessing the Infrastructural-environmental criterion

\begin{tabular}{|c|c|c|c|c|c|c|c|}
\hline \multirow{3}{*}{ infrastructural-environmental } & \multirow{2}{*}{\multicolumn{3}{|c|}{ One-Sample Statistics }} & \multicolumn{4}{|c|}{ One-Sample Test } \\
\hline & & & & \multicolumn{4}{|c|}{ Test Value $=3$} \\
\hline & Mean & $\begin{array}{c}\text { Std. } \\
\text { Deviation }\end{array}$ & $\begin{array}{l}\text { Std. Error } \\
\text { Mean }\end{array}$ & $\mathrm{t}$ & Sig & $\begin{array}{c}\text { Mean } \\
\text { Difference }\end{array}$ & $\begin{array}{l}95 \% \text { Confidence Interval of the } \\
\text { Difference }\end{array}$ \\
\hline
\end{tabular}




\begin{tabular}{|c|c|c|c|c|c|c|c|c|}
\hline & & & & & & & Upper & Lower \\
\hline$] 1[$ & 2.73 & 1.14 & 0.057 & -4.69 & 0.000 & -0.27 & -0.38 & -0.16 \\
\hline$] 2[$ & 2.93 & 1.15 & 0.058 & 1.25 & 0.21 & -0.07 & -0.19 & 0.04 \\
\hline$] 3[$ & 2.78 & 1.11 & 0.056 & -4.00 & 0.000 & -0.22 & -0.33 & -0.11 \\
\hline$] 4[$ & 2.82 & 1.09 & 0.055 & -3.23 & 0.001 & -0.178 & -0.29 & -0.07 \\
\hline$] 5[$ & 2.50 & 0.85 & 0.043 & - & 0.000 & -0.50 & -0.59 & -0.42 \\
\hline
\end{tabular}

\subsection{Combining the Value of the Indicators and Summing Up Each Criterion}

In the previous discussions, the status of the criteria related to each criterion were individually tested and analyzed. Now, it is time to see the status of the criteria in general. For this purpose, we obtained a final value (Table 10) for each criterion (based on Lakert scale encoded from one to five) by combining and averaging the values related to the indicators of each criterion, and assessed it by one-sample T-test. The results of the test reveal that the socio-cultural criterion had a more favorable status than the other criteria in the confidence level of 95 percent, and that this criterion was generally in a better position than the average level, and the other criteria were lower than the average level and were relatively unfavorable, and the weakest status goes to the economic criterion.

Table 10. Combining the value of the indicators and summing up each criterion

\begin{tabular}{|c|c|c|c|c|c|c|c|c|}
\hline \multirow{4}{*}{$\begin{array}{c}\text { Combining the value of the } \\
\text { indicators }\end{array}$} & \multirow{2}{*}{\multicolumn{3}{|c|}{ One-Sample Statistics }} & \multicolumn{5}{|c|}{ One-Sample Test } \\
\hline & & & & \multicolumn{5}{|c|}{ Test Value $=3$} \\
\hline & \multirow[t]{2}{*}{ Mean } & \multirow{2}{*}{$\begin{array}{c}\text { Std. } \\
\text { Deviation }\end{array}$} & \multirow{2}{*}{$\begin{array}{c}\text { Std. Error } \\
\text { Mean }\end{array}$} & \multirow[t]{2}{*}{$\mathrm{t}$} & \multirow[t]{2}{*}{ Sig } & \multirow{2}{*}{$\begin{array}{c}\text { Mean } \\
\text { Difference }\end{array}$} & \multicolumn{2}{|c|}{$\begin{array}{l}95 \% \text { Confidence Interval of } \\
\text { the Difference }\end{array}$} \\
\hline & & & & & & & Upper & Lower \\
\hline health & 2.91 & 0.866 & 0.043 & -2.13 & 0.033 & -0.092 & -0.177 & -0.007 \\
\hline Socio-cultural & 3.16 & 0.697 & 0.034 & 4.54 & 0.000 & 0.158 & 0.089 & 0.227 \\
\hline economic & 2.52 & 0.83 & 0.041 & 11.63 & 0.000 & -0.483 & -0.564 & 0.401 \\
\hline infrastructural-environmental & 2.75 & 0.818 & 0.040 & -6.08 & 0.000 & -0.249 & -0.329 & -0.168 \\
\hline
\end{tabular}

\section{A review of the Hypotheses}

4-1- The first hypothesis: It seems that district 6 of Isfahan does not enjoy a favorable status by criteria of a healthy city. This hypothesis was assessed by combining the value of the indicators and summing up each criterion. For this purpose, first the average values of the criteria under study were calculated and tested on the basis of value 3 (average of the responses in the scale used). As the calculated significance level $(\operatorname{sig}=0.000)$ is less than the considered significant level $(\alpha=005)$, the test's significance at the confidence level of 95 percent -and higher- is acceptable. As the T-statistics was negative, we can come to the conclusion that the criteria of district 6 of Isfahan has negative distance with the average level, and the hypothesis of unfavorableness of healthy city criteria in this district is confirmed.

Table 11. Assessment of all the criteria - all criteria of district 6 of Isfahan 


\begin{tabular}{|c|c|c|c|c|c|c|c|c|}
\hline & & & & & & One-s & ple Test & \\
\hline & & קеte & & & & Test & ue $=3$ & \\
\hline & Mean & Std. & Std. Error & $\mathrm{t}$ & Sig & Mean & $\begin{array}{l}95 \% \text { Confic } \\
\text { Difference }\end{array}$ & erval of the \\
\hline & & & & & & & Upper & Lower \\
\hline total & 2.77 & 0.684 & 0.034 & $\begin{array}{c}- \\
6.831\end{array}$ & 0.000 & -0.233 & -0.301 & -0.166 \\
\hline
\end{tabular}

4.2 The Second Hypothesis: There Exists a Significant Difference Between the Citizens' Education Level and Their Attitude toward Healthy City Criteria in District 6 of Isfahan.

Pearson correlation coefficient was used to test this hypothesis. The significance level obtained for the whole criteria is more than the considered level $(\alpha=0.05)$, which shows that there is no significant association between the citizens' education level and their attitude toward healthy city criteria ${ }^{3}$, and this hypothesis is not confirmed.

Table 12. Pearson results on the association between the citizens' education level and healthy city criteria.

\begin{tabular}{|c|c|c|c|c|c|}
\hline criteria & health & Socio-cultural & economic & Infrastructural- environmental & total \\
\hline Pearson Correlation & 0.058 & 0.001 & 0.064 & 0.072 & 0.065 \\
\hline sig & 0.247 & 0.981 & 0.202 & 0.151 & 0.196 \\
\hline
\end{tabular}

4.3 The Third Hypothesis: There Exists a Significant Relation among Healthy City Criteria Investigated in District 6 of Isfahan.

This hypothesis was also tested using Pearson correlation coefficient. The results reveal that there is a direct relation among all of the criteria in the confidence level of 99 percent, though the intensity of the relation among them is different. Between the health criterion and the economic criterion, the health criterion and the infrastructural-environmental criterion, and the economic criterion and the infrastructural-environmental criterion exists a direct strong relation, but there exists a direct average relation between the socio-cultural criterion and the health criterion, as well as between the socio-cultural criterion and the infrastructural-environmental criterion. However, the relation between the cultural criterion and the economic criterion is weak (Table 13).

\begin{tabular}{|l|l|c|c|c|c|}
\hline \multicolumn{2}{|c|}{ criteria } & health & Socio-cultural & economic & $\begin{array}{c}\text { infrastructural-envir } \\
\text { onmental }\end{array}$ \\
\hline \multirow{3}{*}{ health } & Pearson Correlation & $*$ & $0.434(* *)$ & $0.916(* *)$ & $0.915(* *)$ \\
\cline { 2 - 6 } & Sig. (2-tailed) & $*$ & 0.000 & 0.000 & 0.000 \\
\hline \multirow{3}{*}{ Socio-cultural } & Pearson Correlation & $*$ & $*$ & $0.259(* *)$ & 0.508 \\
\cline { 2 - 6 } & Sig. (2-tailed) & $*$ & $*$ & 0.000 & 0.000 \\
\hline \multirow{3}{*}{ economic } & Pearson Correlation & $*$ & $*$ & $*$ & 0.858 \\
\cline { 2 - 6 } & Sig. (2-tailed) & $*$ & $*$ & $*$ & 0.000 \\
\hline
\end{tabular}

\footnotetext{
3 - In addition to the high sig, considering the correlation obtained, one may conclude that there is no considerable (significant or insignificant) relation found between the two categories.
} 


\begin{tabular}{|l|l|c|c|c|c|}
\hline \multirow{2}{*}{$\begin{array}{l}\text { infrastructural-envir } \\
\text { onmental }\end{array}$} & Pearson Correlation & $*$ & $*$ & $*$ & $*$ \\
\cline { 2 - 6 } & Sig. (2-tailed) & $*$ & $*$ & $*$ & $*$ \\
\hline
\end{tabular}

**. Correlation is significant at the 0.01 level (2-tailed).

4.4 The Fourth Hypothesis: Gender Affects the Citizens'Attitude toward Criteria of A Healthy City, and Males and Females Have difference Attitudes toward Healthy City Criteria in District 6 of Isfahan.

In order to test this hypothesis, we used the two-group average comparison test (T-independent) and compared the gender of the respondents with each criterion of a healthy city. As the calculated significant level in all cases was more than the considered significant level $(\alpha=005)$ in both cases of equal and unequal variance, there is no significant difference between males and females' attitudes toward healthy city criteria in district 6 of Isfahan, and this hypothesis is rejected.

Table 13. The results of the relation between gender and criteria of a healthy city.

\begin{tabular}{|c|c|c|c|c|c|c|c|c|c|}
\hline & & \multicolumn{8}{|c|}{ Levene's Test } \\
\hline & & \multirow[t]{2}{*}{$\mathrm{F}$} & \multirow[t]{2}{*}{ Sig } & \multirow[t]{2}{*}{$\mathrm{t}$} & \multirow{2}{*}{$\begin{array}{l}\text { Sig. (2- } \\
\text { tailed) }\end{array}$} & \multirow[t]{2}{*}{ Mean } & \multirow{2}{*}{$\begin{array}{l}\text { Std. } \\
\text { Error }\end{array}$} & \multicolumn{2}{|c|}{$\begin{array}{c}\text { 95\% Confidence Interval } \\
\text { of the Difference }\end{array}$} \\
\hline & & & & & & & & Lower & Upper \\
\hline \multirow{2}{*}{ health } & $\begin{array}{l}\text { Equal variances } \\
\text { assumed }\end{array}$ & 0.003 & 0.954 & -1.3 & 0.192 & $\begin{array}{c}- \\
0.115\end{array}$ & 0.882 & -0.288 & 0.0582 \\
\hline & $\begin{array}{l}\text { Equal variances } \\
\text { not assumed }\end{array}$ & - & - & -1.3 & 0.193 & $\begin{array}{c}- \\
0.115\end{array}$ & 0.884 & -0.289 & 0.0586 \\
\hline \multirow{2}{*}{ Socio-cultural } & $\begin{array}{l}\text { Equal variances } \\
\text { assumed }\end{array}$ & 0.006 & 0.938 & $\begin{array}{c}- \\
0.947\end{array}$ & 0.344 & 0.067 & 0.071 & -0.208 & 0.072 \\
\hline & $\begin{array}{l}\text { Equal variances } \\
\text { not assumed }\end{array}$ & - & - & $\begin{array}{c}- \\
0.947\end{array}$ & 0.344 & 0.067 & 0.711 & & 0.072 \\
\hline \multirow{2}{*}{ Economic } & $\begin{array}{l}\text { Equal variances } \\
\text { assumed }\end{array}$ & 1.77 & 0.183 & -1.44 & 0.149 & $\begin{array}{c}- \\
0.122\end{array}$ & 0.084 & -0.28 & 0.04 \\
\hline & $\begin{array}{l}\text { Equal variances } \\
\text { not assumed }\end{array}$ & - & - & -1.41 & 0.157 & $\begin{array}{c}- \\
0.122\end{array}$ & 0.086 & -0.29 & 0.04 \\
\hline \multirow[t]{2}{*}{ infrastructural-environmental } & $\begin{array}{l}\text { Equal variances } \\
\text { assumed }\end{array}$ & 0.113 & 0.737 & $\begin{array}{c}- \\
0.534\end{array}$ & 0.594 & -0.04 & 0.08 & -0.20 & 0.11 \\
\hline & $\begin{array}{l}\text { Equal variances } \\
\text { not assumed }\end{array}$ & - & - & $\begin{array}{c}- \\
0.532\end{array}$ & 0.59 & -0.04 & 0.08 & -0.20 & 0.12 \\
\hline \multirow{2}{*}{ total } & $\begin{array}{l}\text { Equal variances } \\
\text { assumed }\end{array}$ & 0.119 & 0.73 & -1.2 & 0.228 & -0.08 & 0.06 & -0.22 & 0.052 \\
\hline & $\begin{array}{l}\text { Equal variances } \\
\text { not assumed }\end{array}$ & - & - & -1.2 & 0.23 & -0.08 & 0.07 & -0.22 & 0.053 \\
\hline
\end{tabular}

\section{Concluding Remarks and Suggestions}

A city should enable its residents to make use of its privileges, that is, it should present its 
citizens with different services and facilities to the most possible extent, and at the same time it should pave the way for equal use of the services and facilities by all groups, including the vulnerable people (women, children, and disabled and old people. A subject that can cover the mentioned concepts is "healthy city". The results of this research are:

District 6 of Isfahan does not enjoy a favorable status in healthy city criteria, so that the economic criterion with the average of 2.52 , the infrastructural-environmental criterion with the average of 2.75 , and the health criterion with the average of 2.91 respectively have an unfavorable status lower than the average level. Finally, the socio-cultural criterion with the average of 3.16 was higher than the average level and had a relatively favorable status.

There is a significant relation between the citizens' education level and their attitudes toward healthy city criteria in district 6 of Isfahan.

The relation among healthy city criteria in this district shows that there is a direct relation among the criteria.

\section{Strategies and Suggestions}

Based on the results, we recommend the following strategies for the long-term planning (city for all citizens, city free from pollution, citizens' access to welfare, and citizens' raised quality of life etc.):

1.Increasing the fair distribution of job opportunities, job security, useful and non-false jobs and $\ldots$

2. Reducing the taxes and charges, costs of water, gas, telephone, transportation, etc.

3. Making use of ICT (Information and communication technology), non-motorized and public transportation, and ...

4. Accessible parks, green spaces of squares and boulevards, urban jungles, home gardens, green roofs and so on.

5. Use of insulating glass, and insulating the constructions, savings in consuming water, electricity, gas, and other resources, segregation of the garbage at home, and so on.

6. Appropriate access to health-medical service centers, existence of medical cares for all citizens, the status of medical services insurance etc.

7. Waste disposal and reduction of environmental pollutions, cleanliness of the streets, and public spaces and places.

8. Healthy water, proper nutrition and clothing.

9. Safety, sports and physical activities, avoiding smoking cigarettes and drugs, lack of communicable or hereditary diseases, mental or psychological status etc.

10. Increasing participation in managing the urban and social affairs and local decisions, holding ceremonies, sense of city and its facilities' belonging to all citizens and responsibility for it, cooperation and collaboration. 
11. Encouraging the type of behavior and clothing, observing the rules and regulations, respecting the values and norms and so on.

\section{Reference}

Abdi Danesh Pour, Z. (2000). analyze the spatial inequality in the cities, case study Tehran, Journal of sofe, year IX, No. 29.

Ahmad, H. (1998). Healthy Cities: A Comprehensive Approach to Public Health, Copyright 1998-1999- The Rural Health Policy Program at Virginia Tech.

C. Stephens and D. Satterthwaire, (2008). Urban Health in Developing Countries.

Consulting Engineers Architects and Urban Development Water and Energy Research and Studies, (1993). a healthy city, printing and binding (shahr print).

Department of Health and Human Services, (2001). Healthy people in Healthy Communities, Washington, DC:U.S.A.,P.1.

Edwards, peggy andagis d. tsouros, (2008). A healthy city is an activity city: a physical activity planning guide, Address requests about publications of the WHO Regional Office for Europe to: Publications WHO Regional Office for Europe.

Few, Roger, Harpham. T, Sarah. A, (2003). Urban primary health care in Africa: a comparative analysis of city-wide public sector projects in Lusaka and Dar es Salaam, Health \& Place. http://dx.doi.org/10.1016/S1353-8292(02)00029-1

Galeaa, Sandro, Nicholas Freudenberg, David Vlahova, (2005). Cities and population health, Social Science \& Medicine 60, 1017-1033, http://dx.doi.org/10.1016/j.socscimed.2004.06.036

Goldstein, G, (2000). Healthy Cities: Overview of a WHO international program. Rev. Environ Health; 15(1-2): 207-14. Health Care Services Agency. http://dx.doi.org/10.1515/REVEH.2000.15.1-2.207

Hafez niaa, M. (2008). Introduction to research methods in the humanities, Samt publisher.

Hancock and Duhi (1986). Healthy People for HealthyCity and Healthy Communities, Tulane University.

Innovative monitoring and evaluating the healthy cities initiative of Jin-Ju city-Korea. (2005).

Jose san, (2008). Urban growth management, West Virginia University Press.

Lawrence, J, R., \& Fudge, C. (2009). "Healthy cities in global and regional context". health promotion international .15. http://dx.doi.org/10.1093/heapro/dap051

Lynch, k, (2006). Rural- urban Interaction in the developing world, rout ledge, London.

McKeehan , I. V. (2000). A multilevel city health profle of Moscow Faculty of Public Health, Bielefeld University, Germany, Social Science \& Medicine 51.

Mousa Kazem Mohammadi, M. (2005). Sustainable urban development: concepts and 
perspectives, Geographical Research Quarterly, No. 3.

Nasrabadi, A. (2006). social integration and public participation, Humanities reserch, Number 6

Northridge, M., D. Sclar, E., \& Biswas, P. (2003). "Sorting out the connections between the built environment and health: a conceptual framework for vavigating pathway and planning healthy cities". Urban health.p 556. http://dx.doi.org/10.1093/jurban/jtg064

Ottawa Charter for health promotion, (1986). Health Promotion, p.4.

Papoly Yazdi, M., \& Rajabi, H. (2004). Town and Hinterland_Theories, Samt publisher.

Participating Organizations, Spring Celebration event recognizes fiftyHealthy City Action Participants Plan by vol. 1, 2006.

Rahnema, M. R, Z., Afshar and Mohammad Mohsen Razavi (2010). analyzing the characteristics of healthy city in Baharestan neighborhood $\neg$ Mashhad, Urban and Planning Management Conference, 31 April and first of May, Mashhad

Shakooi, H, (1991). Social geography of cities.

Shakooi, H, (2006). New perspectives on the history and philosophy of geography, Volume II, published by Gitashenasii.

Sheikhi, M. T. (2000). New perspectives in the healthy cities management, Proceedings of the sustainable urban management, Tabriz Municipality.

Taipei Healthy City Project. (2005). Taipei Healthy City Project\& profile , 26-63.

The first Healthy City Symposium Proceedings, (1992). Tehran, Department of Public and International Relations of Tehran

Thompson, Susan, (2007). Health planning Forum, premier's Council. UNESCO (United Nations Educational, Scintific and Cultural Organization) Institute for Statistics. 2007a.http://www.unesco.org/. WHO, 1995, Buihdhng Heahty City: A Practitionevs Guide Manual Prepaved By The Unity Of Urban Environmental Health World Organization

WHO, (1997). Healthy Vending Guidelines, 1997, WHO Regional Office for Europe.

World Health Organization, (1994). Determinants of health: the solid facts, Geneva, Switzerland.

World Health Organization, (2000). Determinants of health: the solid facts, Geneva, Switzerland.

World Health organization, (2010). Why urban health matters, 2010: A year-long focus on urbanization and health.

Yghfory, H., S. Rafieian, Abdullah Razdasht (2011). Public spaces as a factor in increasing social Integration, the second National Conference of Sabzevar 


\section{Macrothink \\ Environmental Management and Sustainable Development \\ ISSN 2164-7682 \\ 2015, Vol. 4, No. 1}

Ziary, Karamat Ullah, (2006). New town planning, Samt publisher.

\section{Copyright Disclaimer}

Copyright for this article is retained by the author(s), with first publication rights granted to the journal.

This is an open-access article distributed under the terms and conditions of the Creative Commons Attribution license (http://creativecommons.org/licenses/by/3.0/). 